орієнтовану семантику, а формують модальний план висловлення сукупно з іншими лінгвальними та паралінгвальними засобами (просодичними, лексико-граматичними, синтаксичними тощо).

\title{
Література:
}

1. Балли Ш. Общая лингвистика и вопросы французского языка. М. : Издательство иностранной литературы, 1955. 416 с.

2. Бенвенист Э. Общая лингвистика. М. : Прогресс, 1974. 446 с.

3. Бріцин В. М. Модальність і предикативність: лінії розмежування і протиставлення. Мовознавство. 2015. № 2. С. 77-85.

4. Вихованець I. Р.Граматика української мови. Синтаксис. К. : Либідь, 1993. 368 с.

5. Доценко О. Л. Семантико-прагматичний синтаксис : особливості вираження модальності. К. : Міленіум, 2006. 226 с.

6. Каранська М.У. Синтаксис сучасної української літературної мови. К. : НМКВО, 1992. 399 с.

7. Сучасна українська літературна мова : Синтаксис / [за заг. ред. І.К. Білодіда]. К. : Наукова думка, 1972. 515 с.

8. Теньер Л. Основы структурного синтаксиса. М. : Прогресс, 1988. $656 \mathrm{c}$.

9. Ткачук В. М. Категорія суб'єктивної модальності. Тернопіль : Підручники й посібники, 2003. 240 с.

10. Шинкарук В. Д. Модус і диктум у структурі речення : дис. ... Д-ра філол. наук : 10.02.01. Чернівці, 2003. 465 с.

DOI https://doi.org/10.30525/978-9934-588-90-7-11

\section{СЕМАНТИКА СУБ'ЄКТА ЯК ГОЛОВНИЙ ЧИННИК КОНСТРУЮВАННЯ СИНТАКСИЧНОЇ СТРУКТУРИ}

\author{
Сулима О. П. \\ кандидат філологічних наук, \\ дочент кафедри української мови
}

Національний педагогічний університет імені М. П. Драгоманова м. Київ, Украӥна

У середині XX ст. у світовому та українському мовознавстві популярною стала вербоцентристська теорія, згідно з якою компоненти структури речення поділяються на облігаторні, передбачені валентністю предиката, - та сирконстанти, необов'язкові. У $80-\mathrm{x}$ pp. ХХ ст. 
Ч. Філлмор зауважував, що ідея виняткової ролі дієслова в реченні не враховує зворотний вплив конструктів, зокрема суб'єкта, які не лише актуалізують окремі семи дієслівної лексеми, але й здатні формувати загальний смисл висловлюваного. Саме ідея рівноправності предикатної та суб'єктної синтаксем, їхній обопільний вплив на структуру синтаксичної конструкції є основою пропонованого дослідження.

Розвиток вербоцентристської теорії у другій половині XX ст. паралельний становленню функціональної граматики. Саме функціональна сфера дієслівної лексики семантично ширша, оскільки дієслова мають найбільший потенціал до метафоризації i граматикалізації. Причому чим більша кількість семем дієслова, тим більша здатність до переносного уживання. Крім того, окремі значення того самого дієслова можуть бути настільки віддалені одне від одного, що належать до різних лексико-семантичних груп: «Ємність сигніфікатора, відображуваного в змістовій структурі багатозначного слова, виявляється в тому, що кожне 3 лексичних значень виражає лише певні окремі аспекти сигніфіката 3 різною мірою їх узагальнення, що, зокрема, може пояснити можливість слова мати понад одне основне вільно-номінативне значення, кожне 3 яких пов'язано з іншим не відношенням субординації, а відношенням взаємної детермінації» [6, с. 42]. Тому спиратися лише на перше, начебто пряме, значення необгрунтовано, оскільки воно - автосемантичне, «не визначається контекстом, тоді, як інші (часткові) значення до семантичних елементів головного значення додають ще й елементи контексту» [1, с. 246]. На це також вказував М. Мірченко: «Предикат не слід також асоціювати (ототожнювати) тільки 3 дієсловами, оскільки дієслово як лексико-граматична категорія є лише семантичним (одним із семантичних, хоч і найпоширенішим) різновидом предиката» [3, с. 112].

С обмежена кількість дієслів, що, наприклад, позначають напрям руху (вийти, зайти, виїхати, заӥхати), в яких префікси актуалізують семантику суб'єкта та другорядних поширювачів, адже саме префікси «скорочують обсяг лексико-семантичних сполучувальних можливостей твірного дієслова, а також сприяють формуванню нових позицій» [2, с.93]. Проте дієслова тієї ж лексико-семантичної групи переходити, вилітати, перелітати тощо - такої властивості не мають, оскільки на загальний зміст речення впливають інші компоненти. Порівняйте: 1) Пішохід має переходити дорогу у призначеному місиі; 2) Після екзаменаційної сесї всі студенти перейшли на 2 курс; 3)Вранці дружина йде на роботу, син $і$ донька - до иколи. 3 другої половини дня стіл переходить y $\ddot{x}$ розпорядження (Я. Гримайло) тощо. У третьому прикладі загальний зміст висловлення мотивований темпоративом після екзаменаційної сесії; у прикладі 3 - контекстом та семантикою суб'єкта, вираженого іменником стіл. Реципієнт не може правильно встановити 
можливе значення синтаксичної конструкції, оскільки перші значення дієслова переходити - «1. Йдучи, переправлятися через що-небудь або на другий бік чого-небудь. 2. Проходити якийсь простір, яку-небудь віддаль і т. ін.» [4, Т. 6, с. 310] - не пов'язані з контекстами прикладів 2 , 3. Тому дослідження, що грунтуються на спробах пояснити загальний зміст речення з різними типами дієслів у функції присудка через аналіз відносно невеликої кількості так званих ядерних речень, невиправдані, на що звертав увагу Дж. Лайонз [7, с. 468].

На загальний зміст висловлення впливає не лише семантика структурних компонентів, але й загальна тема повідомлення, стильові особливості тощо. Передбачити структурну схему простого речення в офіційно-діловому тексті можливо, оскільки він характеризований однозначністю, уживанням слів у прямому значенні, тавтологією тощо. Розмовний або художній стиль передбачають наявність широкого підтексту, двозначності, натяків, алегорій тощо. Окремі елементи навіть можуть бути невербалізовані, зокрема, в еліптичних реченнях, однак реципієнт мислить їх і адекватно сприймає висловлене. Наприклад, речення На підвіконні - квіти, звичне для розмовного або художнього тексту, вільно відтворюване, незважаючи на відсутність предиката. Слухач уточнює семантику дієслівної лексеми за ширшим контекстом: ростуть, є, видно.

Варто зауважити, що в науковому стилі обставинні компоненти переважно виступають уточнювальним компонентом предикативного значення. Наприклад, у реченнях Граничний вік більшості видів берез не перевищує 100-120 років, у берези жовтої - 150 років, окремі дерева досягають 300 років; Бруньки берези містять ефірні олї, сапонін, глюкозу, смолу, бетулоретинову кислоту, а листки - антоціани, кумарини, флаваноли, сапоніни, ефірні олії, смолу, каротин, вітамін С; Незначна кількість видів [моху] росте в посушливих місиях, наприклад у степах. Деякі види ведуть епіфітний спосіб життя на корі дерев або у воді дієслівні форми втрачають значення процесуальності і виражають лише вказівку на постійну, позачасову предикативну ознаку [докладніше 5]. Такі трансформації значення можна простежити на прикладі речень Хлопчик обпік руку та Вогонь обпікає шкіру. У першому реченні дієслово зберігає значення «Вогнем або чим-небудь гарячим пошкоджувати шкірні покриви, слизові оболонки» $[4$, Т. 5 , с. 556], а загальний смисл висловлення - це тимчасові, випадкові вияви, проте в другій конструкції предикат має характеризувальне значення, оскільки обпікати - постійна властивість суб'єкта вогонь.

Крім того, значна частина дієслів в певних умовах здатна втрачати основні семи, зближуючись за своїми синтаксичними зі зв'язками. Граматикалізація, часткова або повна втрата лексичного значення, дієслів 48 
зафіксована в конструкціях з суб'єктами-неістотами: Ліси стоять зелені, у яких дієслово позбавлене семантики і тотожне абстрактній дієслівній зв'язці бути. Так само в дієслівно-іменних описових зворотах дієслово втрачає свою першість, оскільки переважно виступає виразником граматичних значень, а головним лексичним компонентом $\epsilon$ іменник: мати право, мати слово, мати ціну, мати значення, мати вплив тощо.

Отже, дієслівна лексема певною мірою дозволяє передбачити структуру речення, однак роль суб'єктної синтаксеми переважно $є$ визначальною. Це пов'язано з тим, що сама по собі дієслівна лексема не асоційована в мовців $з$ можливістю метафоризації або граматикалізації, оскільки реципієнт сприймає передусім перше, пряме значення дієслова. Дальші дослідження можуть бути спрямовані у сферу експериментального дослідження валентнісних характеристик окремих лексико-семантичних груп дієслівної лексики.

\section{Література:}

1. Курилович Е. Очерки по лингвистике. Москва: Издательство иностранной литературы, 1962.

2. Михайлова О.А. Особенности функционирования глаголов со специализированными субъектными семами в основном и неосновном значении. Классы глаголов в функциональном аспекте. Свердловск: УрГУ, 1986. С. 33-37.

3. Мірченко М.В. Структура синтаксичних категорій. Вид. 2-ге, переробл. Луцьк: РВВ «Вежа» Волинського державного університету імені Лесі Українки, 2004. 393 с.

4. Словник української мови: у 11 томах / АН УРСР. Інститут мовознавства; за ред. І. К. Білодіда. Київ : Наукова думка, 1970-1980.

5. Сулима О. П. Проблема системного опису дієслівної семантики. Актуальні питання гуманітарних наук : міжвузівський збірник наукових праць молодих вчених Дрогобицького державного педагогічного університету імені Івана Франка [редактори-упорядники В. Ільницький, А. Душний, І. Зимомря]. Дрогобич : видавничий дім «Гельветика», 2019. Вип. 25. С.148-154.

6. Сулименко Н.Е. Общие вопросы типологии лексических значений слова одного лексико-грамматического класса. Глагол в лексической системе современного русского языка. Ленинград: ЛГПИ, 1981. C. 32-57.

7. Lyons J. Semantics. London : CUP, 1977. V. 1-2. 